Bangladesh J. Plant Taxon. 26(2): 325-327, 2019 (December)

(C) 2019 Bangladesh Association of Plant Taxonomists

\title{
AZOLLA MICROPHYLLA KAULF. (SALVINIACEAE): A NEW PTERIDOPHYTIC RECORD FOR BANGLADESH
}

\author{
Md. Almujaddade Alfasane ${ }^{1}$, Rauf Ahmed Bhuiyan, Jesmin Akhter Jolly \\ AND SHAHIMA ISLAM ${ }^{2}$ \\ Department of Botany, University of Dhaka, Dhaka 1000, Bangladesh
}

Keywords: Azolla microphylla Kaulf; Salviniaceae; New record; Bangladesh.

Azolla Lam., a pteridyphytic genus is represented by only seven species throughout the world and in Bangladesh this genus is constituted by two species, namely A. pinnata $\mathrm{R}$. Br. and A. filiculoides Lam. Azolla are weeds in many countries of the world, covering some water bodies entirely (Ahmed et al., 2009. http://www.theplantlist.org/1.1/browse/P/Salviniaceae/Azolla/). Azolla are used for biological control of mosquito in many countries of the world. Azolla is a highly productive plant. It doubles its biomass in 1.9 days or more, depending on conditions, and yield can reach up to10 tonnes fresh matter/ha in Asian rice fields (Hasan and Chakrabarty, 2009). $37.8 \mathrm{t}$ fresh weight/ha (2.78 t DM/ha dry weight) has been reported for Azolla pinnata in India (Ahmed et al., 2009).

The plant materials of this study were collected through a hydrobiological expedition carried out in a natural Haor, namely Kuniar Haor located at the Baribari union under Itna upazila of Kishoreganj district in the northern part of Bangladesh. Geographically, the Haor is located between $24^{\circ} 49^{\prime} 94.40^{\prime \prime} \mathrm{N}$ to $24^{\circ} 50^{\prime} 03.23^{\prime \prime} \mathrm{N}$ latitude and $91^{\circ} 00^{\prime} 95.84^{\prime \prime} \mathrm{E}$ to $91^{\circ} 00^{\prime} 97.07^{\prime \prime} \mathrm{E}$ longitude at an altitude of nearly $46 \mathrm{~m}$ above the mean sea level. This Haor is located at the meeting point of the River Narasunda and the River Danu. The current research work was carried out from May 2019 to September 2019. The sample was collected from the surface near the bank of the Haor with some other aquatic angiosperms in a large air tight polyethylene bag with some water inside. It was transported to the Phycology, Limnology and Hydrobiology Laboratory, Department of Botany, University of Dhaka within six hours of sample collection. Some fresh materials were preserved in $4 \%$ formaldehyde and voucher specimens of the material were prepared and preserved in the laboratory. The remaining plant sample was transferred in a concrete house $(1 \times 0.5 \mathrm{~m}$ length, depth $0.40 \mathrm{~cm})$ in the Botanical Garden, Department of Botany, University of Dhaka for culturing. The specimen has been identified as Azolla microphylla Kaulf by consulting standard literature (Kunze, 1845; Svenson, 1944; Fassett, 1957; Jain et al., 1989; Zimmerman et al., 1989; Fernandez et al., 1993; Wagner, 1997; Fiogbe, 2004, Edward and Hove, 2004; Hasan and Chakrabarty 2009; Dey, 2017). Azolla microphylla Kaulf was not reported earlier in the previous studies or literature, viz. Hooker (1888), Prain (1903), Ahmed et al. (2009) from the areas that now fall under the territory of present Bangladesh. Hence, it is reported here as a new record for Bangladesh.

A detailed taxonomic account along with illustrations of the species has been prepared based on the fresh specimens.

Azolla microphylla Kaulf, Int J. Pl. Sci. 167: 529-538 (2006).

(Fig. 1)

Synonym: Azolla mexicana Schltdl. \& Cham. Ex C. Presl, Pl. Usda.gov. (1996)

Common names: Mexican mosquito fern, Mosquito fern.

${ }^{1}$ Corresponding author: Email: <mujaddade@yahoo.com>

${ }^{2}$ Department of Environmental Management, School of Environmental Science \& Management, Independent University, Bangladesh. 
Prostrate, floating on the water's surface, long, stalk less, alternate, often overlapping, like shingles, along branching stems. Stem up to about $1.3 \mathrm{~cm}$ long, usually branched, typically fanshaped in outline in well-developed plants; new growth bright green to blue-green, often turning dark red later in the season, or having at least some red-tinged leaves. Plants can form large surface area colonies, which sometime cover entire aquatic body, and may form multi-layer mats, up to $3.81 \mathrm{~cm}$ thick. Leaves $65-72 \times 22-38 \mu \mathrm{m}$, divided into 2 lobes, folded, upper lobe above the water's surface, blunt to pointed at the tip, somewhat succulent and covered in short, glass-like hairs, the lower lobe submersed, more membranous and rounded at the tip, the distance between two leaves is around $12-18 \mu \mathrm{m}$.

Note: Different species of Azolla look much alike, and some of them are very difficult to distinguish without size and shape of leaves.
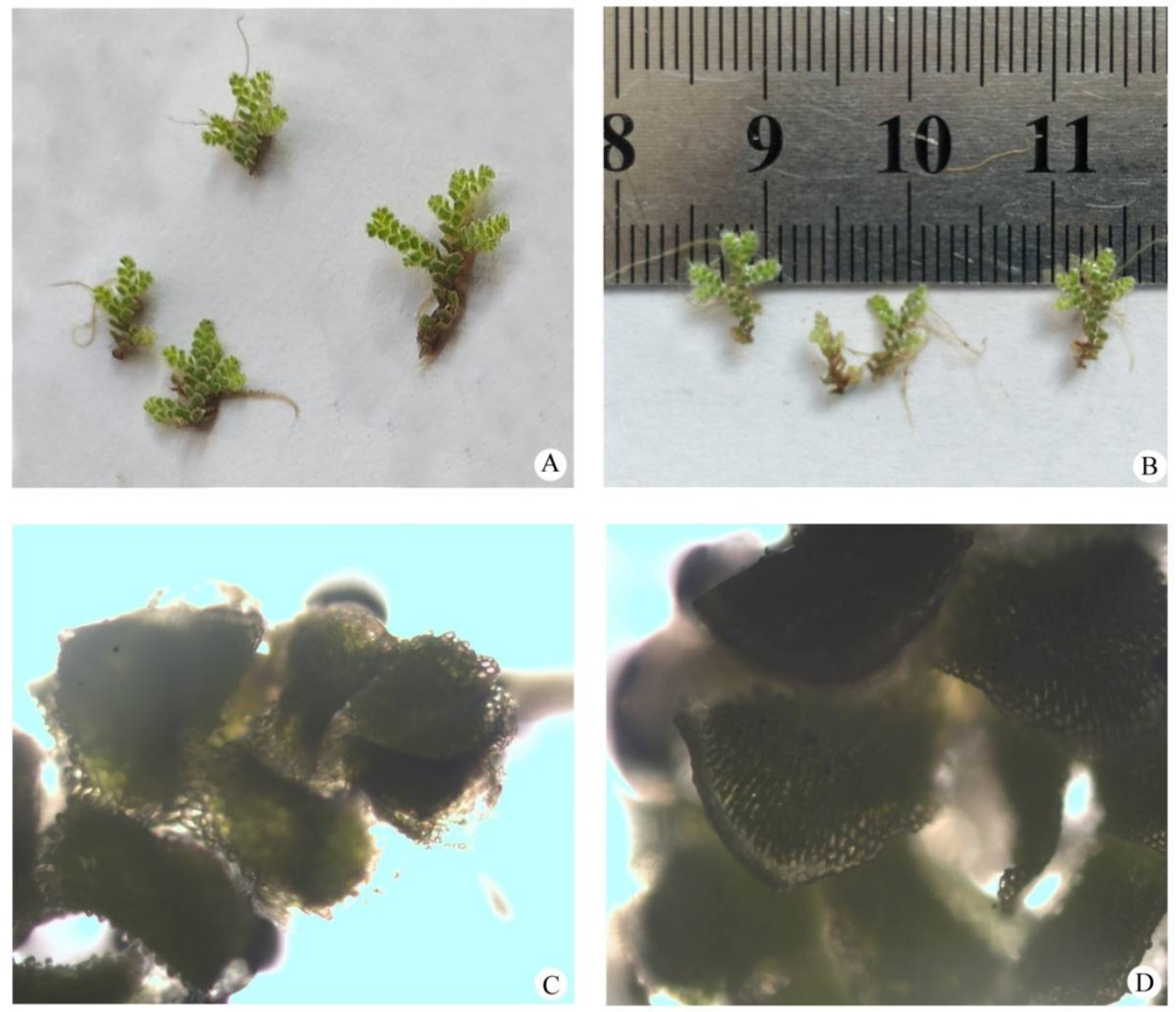

Fig. 1. Azolla microphylla Kaulf.; A. Whole plant; B. Plants showing microscopic leaves; C. Arrangement of upper and lower lobes of leaves; D. Cell arrangements of leaves.

Ecology: Azolla microphylla Kaulf can grow in the edges of Kunier Haor. This species also grows in rice fields, shallow wetlands, slow moving streams, irrigation reservoirs or canals, edges of lakes, ponds, sloughs, or backwaters. A. microphylla Kaulf can grow in water surface and 
tolerates any range of water levels. It can also develop in higher water levels and high-nutrient environments (http://www.theplantlist.org/tpl1.1/record/tro-26608433). Numerous rooting of $A$. microphylla Kaulf were observed in the surface of the Kunier Haor. A. microphylla requires no rooting in bottom sediments.

\section{References}

Ahmed, Z.U., Hassan, M.A., Begum, Z.N.T., Khondker, M., Kabir, S.M.H., Ahmad, M., Ahmed, A.T.A., Rahman, A.K.A. and Haque, E.U. 2009 (Eds). Encyclopedia of flora and fauna of Bangladesh. Vol. 5 Bryophytes, Pteridophytes, Gymnosperms. Asiatic Society of Bangladesh, Dhaka. 390 pp.

Dey, S., Hore, M., Biswas, J., Biswas, M., Mandal, B.K., Das, P. and Gupta, S. 2017. A new record of brown rot disease in water fern Azolla microphylla (Azollaceae): Loss of important bio-resource. Fern Gaz. 20(6): 245-254.

Evrard, F. and Hove, V.C. 2004. Taxonomy of the American Azolla species (Azollaceae): A Critical Review. Systematics and Geography of Plants 74(2): 301-318

Fassett, N.C. 1957. A Manual of Aquatic Plants. The University of Wisconsin Press, Madison, 405 pp.

Fernández, O.A., Sutton D.L., Lallana, V.H., Sabbatini, M.R. and Irigoyen, J.H. 1993. Aquatic weed problems and management in South and Central America. In: Pieterse, A.H. and Murphy, K.J. (Eds), Aquatic Weeds, 2nd Edition. Oxford University Press, Oxford, UK. pp. 406-425.

Fiogbe, E.D., Micha, J.C. and Van, H.C. 2004. Use of a natural aquatic fern, Azolla microphylla as a main component in food for the omnivorous-phytoplanktonophagous tilapia, Oreochromis niloticus L. J. Appl. Ichthyol. 20(6): 517-520.

Hasan, M.R. and Chakrabarty, R. 2009 (Eds). Use of algae and aquatic macrophytes as feed in small scale aquaculture - a review. FAO Fisheries and Aquaculture Technical Paper. No. 531. Rome, FAO. 123p.

Hooker, J.D. 1888. Flora of British India, Vol. 5. L. Reeve \& Co. Ltd., Kent, England. pp. 463-686.

Jain, S.K., Vasudevan, P.K. and Jha, N.K. 1989. Removal of some heavy metals from polluted water by aquatic plants: studies on duckweed and water velvet. Biol. Wastes 28(2): 115-126.

Kunze, G. 1845. Filices a Leiboldio in Mexico lactae. Linnaea 18(3): 302-352.

Prain, D. 1903. (Ind. Rep. 1981). Bengal Plants, Vol. 1. Bishen Singh Mahendra Pal Singh, Dehra Dun, India. $663 \mathrm{pp}$.

Svenson, H.K. 1944. The New World species of Azolla. American Fern Journal 34: 69-84.

Wagner, G.M. 1997. Azolla: A review of its biology and utilization. Bot. Rev. 63(1): 1-26.

Zimmerman, W.J., Lumpkin, T.A. and Watanabe, I. 1989. Classification of Azolla spp., section Azolla. Euphytica 43: 223-232.

(Manuscript received on 16 September, 2019; revised on 10 December, 2019) 